\title{
Native bees are a rich natural resource in urban California gardens
}

\author{
by Gordon W. Frankie, Robbin W. Thorp, \\ Jennifer Hernandez, Mark Rizzardi, Barbara \\ Ertter, Jaime C. Pawelek, Sara L. Witt, Mary \\ Schindler, Rollin Coville and Victoria A. Wojcik
}

\section{Evidence is mounting that pollina-} tors of crop and wildland plants are declining worldwide. Our research group at UC Berkeley and UC Davis conducted a 3-year survey of bee pollinators in seven cities from Northern California to Southern California. Results indicate that many types of urban residential gardens provide floral and nesting resources for the reproduction and survival of bees, especially a diversity of native bees. Habitat gardening for bees, using targeted ornamental plants, can predictably increase bee diversity and abundance, and provide clear pollination benefits.

O utdoor urban areas worldwide are known to support a rich diversity of insect life (Frankie and Ehler 1978). Some insects are undesirable and characterized as pests, such as aphids, snails, earwigs and borers; urban residents are most aware of these. Other urban insects are considered beneficial or aesthetically pleasing, such as ladybird beetles and butterflies; this category includes a rich variety of insects whose roles in gardens go largely unnoticed and are thus underappreciated (Grissell 2001; Tallamy 2009). They regularly visit flowers and pollinate them, an important ecological service.

We report the results of a 2005-to2007 survey of bees and their associations with a wide variety of ornamental plant species in seven urban areas, from Northern California to Southern California. While nonnative honey bees (Apis mellifera) are common in many gardens, numerous California native bee species also visit urban ornamental flowers. Of about 4,000 bee species

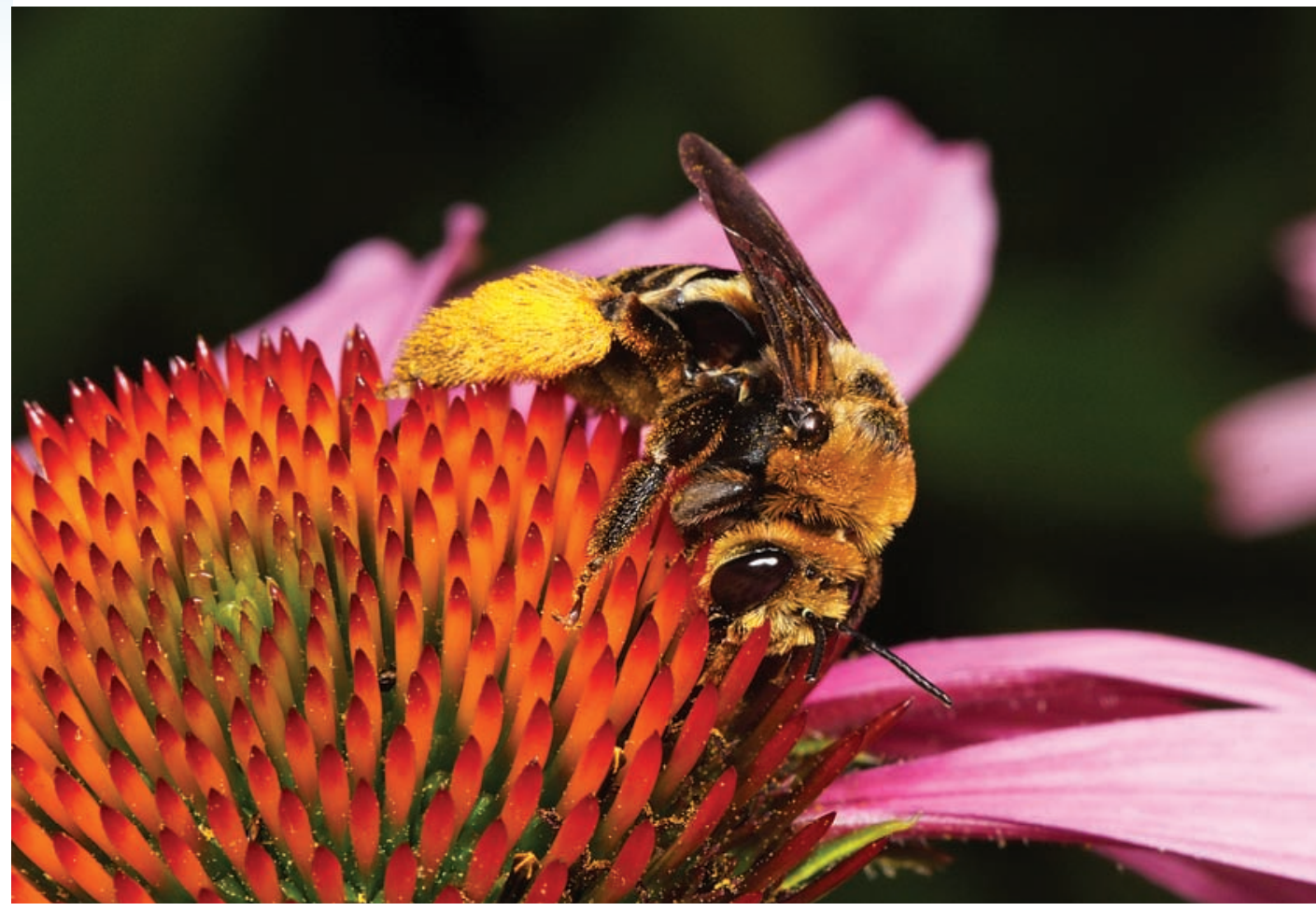

About 1,600 native bee species have been recorded in California. The bees provide critical ecological and pollination services in wildlands and croplands, as well as urban areas. Above, a female solitary bee (Svasta obliqua expurgata) on purple coneflower (Echinacea pupurea).

known in the entire United States, about 1,600 have been recorded in California.

Our recent work on urban California bees in the San Francisco Bay Area (Frankie et al. 2005) is part of a larger movement to conserve and protect native pollinators; participants include the North American Pollinator Protection Campaign and the Xerces Society. Mounting evidence worldwide indicates that pollinators, especially bees, are declining as human populations and urban areas continue to expand (NRC 2007).

Important economic concerns are at stake, in terms of the value of bee pollination in crop systems and wildland environments (Allen-Wardell et al. 1998; NRC 2007). To recognize and protect the pollination services of native bees (Daily 1997), we must learn more about their role in natural environments, crop pollination (Kremen et al. 2002, 2004) and urban areas (NRC 2007). In the urban environment, native bees offer im- portant benefits to people that include aesthetic pleasure, awareness of urban native fauna conservation, pollination of garden plants that provide food for people and animals, and environmental education.

\section{Urban bee surveys}

Previous surveys of ornamental plants in residential neighborhoods of the San Francisco Bay Area (Albany and Berkeley) revealed 82 bee species, of which 78 were native to California and four were nonnative, including the honey bee (Frankie et al. 2005; Hernandez et al. 2009; Wojcik et al. 2008). That work resulted in questions about whether similarly diverse native bees visit ornamental flowers in other urban areas of the state, and whether the same types of bees are associated with the same types of flowers in those urban areas. More specifically, can particular ornamental plants be used as predictors for visitation by certain taxonomic groups of bees over 


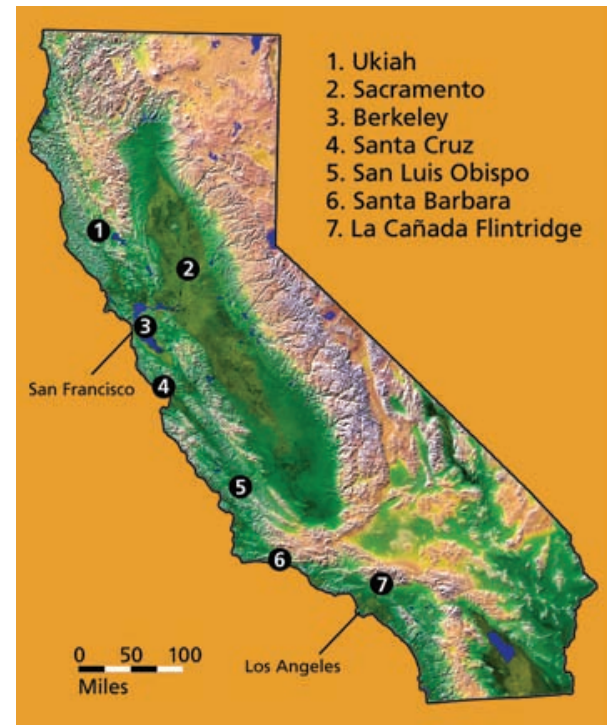

Fig. 1. Ornamental plant and bee survey sites in California.

a wide geographic area, from Northern California to Southern California?

To address these questions, we conducted garden surveys in Albany and Berkeley (Alameda County) and six other medium-large urban areas throughout the state (from north to south): Ukiah (Mendicino County), Sacramento (Sacramento County), Santa Cruz (Santa Cruz County), San Luis Obispo (San Luis Obispo County), Santa Barbara (Santa Barbara County) and La Cañada Flintridge (Los Angeles County) (fig. 1). Ukiah and Sacramento are inland and subject to climatic extremes in winter and summer. Santa Cruz is coastal and has similar conditions to that of Albany and Berkeley. Santa Barbara is coastal, and San Luis Obispo is slightly inland but is also subject to nearby coastal climatic influences. Finally, La Cañada Flintridge is inland, in an upland site near Pasadena.

Neighborhood gardens. We compared gardens in Albany and Berkeley with those in the other six cities. Only gardens in residential neighborhoods were surveyed and evaluated for their bee-attractive ornamental plants. About 30 gardens were visited statewide each year. The main gardens in each of the seven cities were visited 6 to 12 times each year, depending on the city, during the 2005 through 2007 study period.

Bee plant visits. To evaluate the attraction of bees to ornamental flowers, we used visitation or frequency counts

TABLE 1. Ornamental plants and their origins, flowering season and their visitor bee groups in seven California cities, 2005-2007

\begin{tabular}{|c|c|c|c|c|}
\hline $\begin{array}{l}\text { A. Plants with restricted visitor } \\
\text { bee groups }\end{array}$ & Family & Origin* & $\begin{array}{l}\text { Flowering } \\
\text { season }\end{array}$ & Restricted bee groupst \\
\hline Yarrow (Achillea millefolium) & Aster. & CA & Summer & Halictidae \\
\hline Mexican daisy (Erigeron karvinskianus) & Aster. & NN & Spring/summer & $\begin{array}{l}\text { Halictidae, } \mathrm{Hb} \text {, } \\
\text { Megachilidae }\end{array}$ \\
\hline Pumpkins, squash (Cucurbitaceae) & Cucurb. & NN & Summer & Peponapis pruinosa $\ddagger, \mathrm{Hb}$ \\
\hline Manzanita (Arctostaphylos spp.) & Eric. & CA & Spring & Bombus§, $\mathrm{Hb}$ \\
\hline Palo verde (Parkinsonia aculeata) & Fabac. & NN & Summer & Hb, Xylocopa§ \\
\hline Wisteria (Wisteria sinensis) & Fabac. & NN & Spring & Xylocopa§, Hb \\
\hline $\begin{array}{l}\text { Autumn sage (Salvia greggii cvsף// } \\
\text { 'Hot Lips' S. microphylla)\# }\end{array}$ & Lamiac. & NN & Summer & Xylocopa§, Hb \\
\hline $\begin{array}{l}\text { California poppy (Eschscholzia } \\
\text { californica) }\end{array}$ & Papav. & CA & Spring & Bombus§, Halictidae, Hb \\
\hline Sky flower (Duranta erecta) & Verben. & NN & Summer & 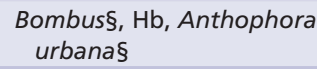 \\
\hline $\begin{array}{l}\text { B. Plants with diverse native bees and } \\
\text { two or three prominent bee groups }\end{array}$ & Family & Origin* & $\begin{array}{l}\text { Flowering } \\
\text { season }\end{array}$ & Prominent bee groups \\
\hline $\begin{array}{l}\text { Blanket flower (Gaillardia x } \\
\text { grandiflora cvs)§ }\end{array}$ & Aster. & NN & Summer & $\begin{array}{l}\text { Melissodes§, Halictidae, } \\
\mathrm{Hb}\end{array}$ \\
\hline Sunflower (Helianthus annuus) & Aster. & CA & Summer & Melissodes§, $\mathrm{Hb}$ \\
\hline Goldenrod (Solidago californica) & Aster. & CA & Summer & $\begin{array}{l}\text { Halictidae, Megachilidae, } \\
\text { Hb, Bombus§ }\end{array}$ \\
\hline Pride of Madeira (Echium candicans) & Borag. & NN & Spring & $\mathrm{Hb}$, Bombus§ \\
\hline Lavender (Lavandula spp.)/cvsף & Lamiac. & NN & Spring/summer & $\mathrm{Hb}$, Bombus§ \\
\hline Russian sage (Perovskia atriplicifolia) & Lamiac. & NN & Summer & $\mathrm{Hb}$, Megachilidae \\
\hline Salvia 'Indigo Spires' & Lamiac. & NN & Summer & Bombus§, Hb, Xylocopa§ \\
\hline Bog sage (Salvia uliginosa) & Lamiac. & NN & Summer & Hb, Xylocopa§, Bombus§ \\
\hline Chaste tree (Vitex agnus-castus) & Lamiac. & NN & Summer & $\mathrm{Hb}$, Megachilidae \\
\hline \multicolumn{5}{|c|}{$\begin{array}{l}\text { * Origin: } \mathrm{CA}=\text { native to California; } \mathrm{NN}=\text { nonnative in California. } \\
\text { † Bee taxa listed from left to right, more frequent to less frequent; } \mathrm{Hb}=\text { honey bee (Apis mellifera) (fam. Apidae). } \\
\text { ₹ Squash bee of the family Apidae. } \\
\text { § Family Apidae. } \\
\text { I cvs = cultivars. These and S. 'Hot Lips' were listed together because of their similar floral structure and reward (nectar), } \\
\text { and because they attracted the same bee taxa. }\end{array}$} \\
\hline
\end{tabular}

for a given plant type whenever we could study a flowering patch that was approximately 1 by 1.5 square yards (1 by 1.5 square meters). We counted visiting bees to each patch for $3 \mathrm{~min}-$ utes on warm, sunny days, and after numerous replicated counts, we determined an average attraction level (Frankie et al. 2005).

Species identification. During the counts, native bees were identified at the species, genus or family level, and honey bees were recorded separately. General notes were also taken on other types of flowering plants adjacent to the target plants, and the bees that visited them. Sometimes a plant type could not be located in a city, or its patch was smaller than the study size. In these cases, we transported potted flowering plants of the target species from Berkeley and made frequency counts on them. The time for leaving potted plants in position before recording bees usually varied from 1 hour to 24 hours.
In a few cases, we returned 3 to 5 days later. Representative (or voucher) bee collections were made for each ornamental plant evaluated, and each collection was taken to UC Davis for species identification. Voucher bee species were pinned, labeled and stored in special insect collection boxes at UC Berkeley.

Target ornamental plants. The 31 target plants were selected for evaluation mostly because they were relatively common in more than half of the surveyed cities and were all known to attract native bee species in Albany and Berkeley (Frankie et al. 2005) (tables 1 and 2). When all species, cultivars and hybrids were considered separately, the target plants actually comprised more than 50 distinct types (Brenzel 2007). Numerous other candidate plants were also evaluated in the statewide survey but not chosen as target plants because they were either rare or only present in some of the cities. Bee visitor groups were compared among the same orna- 
TABLE 2. Ornamental plants and their origins and flowering season visited by diverse bee taxa with no prominent bee groups in seven California cities, 2005-2007

\begin{tabular}{|c|c|c|c|}
\hline Plants & Family & Flowering season & Origin* \\
\hline Monch (Aster $\mathrm{x}$ frikartii) & Aster. & Summer & NN \\
\hline Bidens (Bidens ferulifolia cvs) $†$ & Aster & Spring/summer & NN \\
\hline Coreopsis (Coreopsis grandiflora cvs) $\dagger$ & Aster. & Summer & NN \\
\hline Cosmos (Cosmos bipinnatus) & Aster. & Summer & NN \\
\hline Cosmos (C. sulphureus) & Aster. & Summer & NN \\
\hline Sea daisy (Erigeron glaucus)‡ & Aster. & Spring/summer & CA \\
\hline Black-eyed Susan (Rudbeckia hirta)§ & Aster. & Summer & NN \\
\hline Tansy phacelia (Phacelia tanacetifolia) & Hydro. & Spring & CA \\
\hline Catnip mint (Nepeta spp.)ף & Lamiac. & Spring/summer & NN \\
\hline Rosemary (Rosmarinus officinalis cvs)\# & Lamiac. & Spring/summer & NN \\
\hline Black sage (Salvia mellifera) & Lamiac. & Spring & CA \\
\hline Wild lilac (Ceanothus spp.)** & Rham. & Spring & CA \\
\hline Toad flax (Linaria purpurea) & Scroph. & Spring/summer & NN \\
\hline \multicolumn{4}{|c|}{$\begin{array}{l}\text { * Origin: CA = native to California; NN = nonnative to California. } \\
\text { † cvs = several cultivars. } \\
\text { ₹ Mostly E. glaucus 'Wayne Roderick'. } \\
\text { § Mostly large, single-flower cultivars. } \\
\text { ๆ Mostly catnip mint species (Nepeta x faassenii and Nepeta 'Six Hills Giant'). } \\
\text { \# Several cultivars, especially R. 'Ken Taylor' and R. 'Lockwood de Forest'. } \\
\text { ** Mostly C. 'Ray Hartman', C. 'Julia Phelps' and C. thyrsiflorus 'Skylark'. }\end{array}$} \\
\hline
\end{tabular}

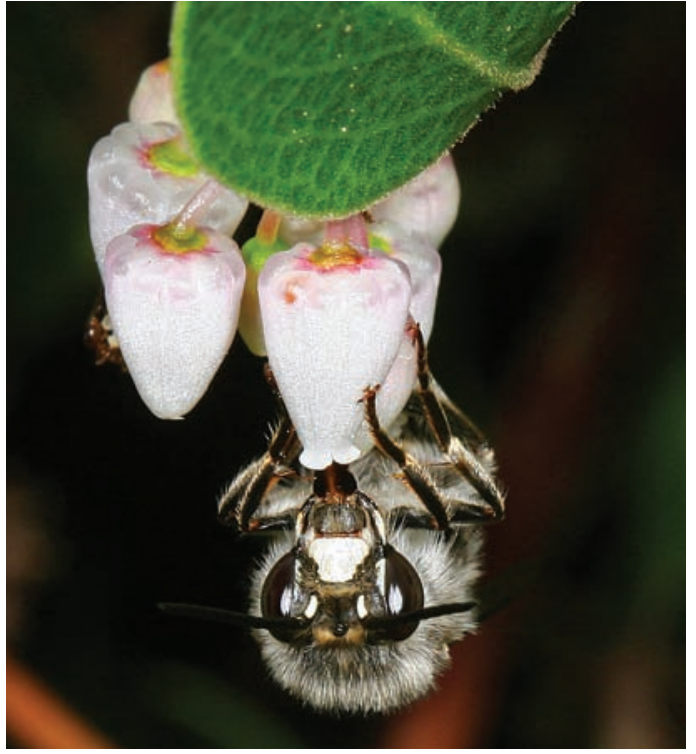

In the seven urban areas studied, specific bees were often associated with particular ornamental plants. Above, a digger bee (Anthophora edwardsii) forages on a manzanita flower (Arctostaphylos sp.). mentals in each city, using as a starting point Albany and Berkeley — where numerous and consistent bee observations and frequency counts had been recorded from 1999 through 2005.

Bee-frequency counts. In late 2005 and early 2006, continuing through 2007, we visited selected gardens periodically to locate those that had a diversity of flowering plants known to attract bees. We then solicited cooperators/owners of gardens and collected voucher bee species from candidate plants (tables 1 and 2). Bee-frequency counts were recorded every 3 to 6 weeks (in San Luis Obispo, counts began in early 2007).

During 2006 and 2007, we made 2,485 3-minute bee-frequency counts, 1,718 from Northern California and 767 from Southern California. Usually one or two but sometimes up to five recorders were present on each count day. Over this survey period, 400 recorder person-days ( 3 to 6 hours of observation and counts) were logged in Northern California and 220 in Southern California.

Bee-frequency counts were not equal for each of the 31 target plant types. Some easily accessible plants — such as cosmos (Cosmos spp.), lavender (Lavandula spp.) and catnip mint (Nepeta spp.) - received high numbers of counts, partly due to their long flowering periods. Other plants - such as manzanita (Arctostaphylos spp.), chaste tree (Vitex agnus-castus) and wild lilac (Ceanothus spp.) - received fewer counts, usually due to a shorter bloom period or difficulty finding enough patches to monitor.

\section{Bee-plant associations}

For almost all target plants, the same characteristically associated bee taxa were found in each of the seven cities. This was especially noticeable with native bees. As expected, nonnative honey bees used a wide variety of ornamentals, and their abundance depended on plant type. The two most attractive plant families to bees were Asteraceae (which provide pollen and nectar) and Lamiaceae (which provide nectar), consistent with the earlier survey results from Albany and Berkeley (Frankie et al. 2005).

Based on bee-frequency counts in the seven cities, we divided the plants into three categories according to their associated bee taxa (tables 1 and 2): (1) those visited by limited (or restricted) bee types, (2) those with diverse native bees that were dominated by a few prominent bee groups and (3) those with diverse native bees that were not dominated by any prominent groups.

Restricted bee types. Nine plants were in the first category, with a limited number of bee taxa (table 1A). While other bee taxa would visit some of these plant types on rare occasions, this plant visitation pattern was consistent in all seven cities. Furthermore, there was no obvious association within this category with plant family, origin or flowering season (table 1A). One of the best plants for observing restricted bee taxa was the widespread California poppy (Eschscholzia californica), where bumble bees (Bombus spp.), small sweat bees (Halictidae) and honey bees were common and predictable visitors. Other good examples included palo verde (Parkinsonia aculeata), wisteria (Wisteria sinensis) and autumn sage (Salvia greggii/ microphylla/cvs.), all of which consistently attracted honey bees and large carpenter bees (Xylocopa spp.).

Diverse native bees/prominent groups. The second category of plants had diverse native bees that were dominated by a few prominent bee groups (table 1B). Each plant type in this category also attracted at least three other bee taxa, but usually at much lower frequencies. These plants were found mostly in two families (Asteraceae and Lamiaceae), were mostly nonnatives (seven of nine) and mostly flowered in summer (seven or eight of nine) (table 1B). Two common examples were blanket flower (Gaillardia x grandiflora) and sunflower (Helianthus annuus), both of which attracted long-horn bees (Melissodes spp.) and honey bees. Blanket flower also attracted halictid bees (Halictidae). Another common example of this plant type was lavender (Lavandula 


\section{Small urban areas can some- times have relatively high percentages of the bee species found in the surrounding geographic region.}

spp./cvs.), which mainly attracted honey bees and Bombus as well as lower frequencies of Xylocopa and leafcutting bees (Megachilidae). As in the first category of plants, these bee-plant associations were consistent throughout the state with few exceptions.

Diverse native bees/no prominent groups. The third category of plants attracted a wide variety of bee species from different genera in at least three families. These plants, again, were mostly from the Asteraceae and Lamiaceae families (10 of 13) and were a mixture of natives and nonnatives that flowered in the spring and/or summer (10 of 13) (table 2). All had long blooming periods, which means that flowers were available to the different types of bees that occurred in a seasonal sequence from spring through summer (Wojcik et al. 2008). This was particularly noticeable for the two-season plants that were visited by spring bees as well as summer bees, which are largely different from each other. The bee-plant associations in this category were consistent wherever the plants were found from Northern California to Southern California.

\section{Urbanization and bees}

Urban bees are those that lived in an area prior to urbanization and were able to adapt to anthropogenic (human) alterations to the environment. In addition, a few exotic species have become naturalized in urban areas of California: honey bees (Apis mellifera), alfalfa leafcutting bees (Megachile rotundata), Megachile apicalis and Hylaeus punctatus. Megachile rotundata is a commercially important leafcutting bee;

\begin{tabular}{|c|c|c|c|}
\hline Location & Families & Genera & Species* \\
\hline & \multicolumn{3}{|c|}{$\cdots \cdot$ no. bee taxa $\cdots}$. \\
\hline Ukiah & 5 & 24 & 67 \\
\hline Sacramento & 5 & 23 & 63 \\
\hline Berkeley & 5 & 25 & 82 \\
\hline Santa Cruz & 5 & 20 & 41 \\
\hline San Luis Obispo & 5 & 24 & 59 \\
\hline Santa Barbara & 5 & 19 & 67 \\
\hline La Cañada Flintridge & 5 & 28 & 73 \\
\hline \multicolumn{4}{|c|}{$\begin{array}{l}\text { * Includes a few morphospecies, morphologically distinct } \\
\text { bee types that could not be immediately associated } \\
\text { with a recorded scientific name. }\end{array}$} \\
\hline
\end{tabular}

Hylaeus punctatus is not considered commercial and belongs to a group called yellow-faced or masked bees.

We identified five bee families and about 60 to 80 species in each city (table 3). Berkeley had the most recorded urban bee species at 82 . We have collected there for several years and continue to add species to our list. At 41, Santa Cruz had the fewest; the severely wet winters and springs of 2005 and 2006 are believed to have greatly reduced native bee populations there. (New collections have been made in 2008 and 2009, and the bee species totals of all the cities continue to increase.)

Some bee species have been found throughout the urban areas surveyed (fig. 1). Those commonly observed are the honey bee, the most common yellow-faced bumble bee (Bombus vosnesenskii), the large carpenter bee (Xylocopa tabaniformis orpifex) and the ultra-green sweat bee (Agapostemon texanus) (table 4).

Specialist bees. Most bees from our sampling are generalist flower visitors with relatively few specialists, where the females collect pollen from only one or a few closely related species of plants. Specialist bees depend on the presence of their favored host flowers for their existence. For example, many specialist bees that occur in the wild areas of the Berkeley hills are not found in nearby urban gardens because their host plants, such as buttercups (Ranunculus californicus) and suncups (Camissonia ovata), are rarely used as ornamentals. We might expect to find males or nectar-seeking females of specialist bee species in gardens near wildlands, as they are not restricted

\begin{tabular}{|c|c|}
\hline Common name & Scientific name \\
\hline \multicolumn{2}{|l|}{ Andrenidae } \\
\hline Mining bee & Andrena angustitarsata \\
\hline \multicolumn{2}{|l|}{$\begin{array}{l}\text { Apidae (Including } \\
\text { Anthophorinae) }\end{array}$} \\
\hline Small digger bee & Anthophora curta \\
\hline Digger bee & Anthophora urbana \\
\hline Honey bee* & Apis mellifera* \\
\hline California bumble bee & Bombus californicus \\
\hline Black-tip bumble bee & Bombus melanopygus \\
\hline $\begin{array}{l}\text { Yellow-faced bumble } \\
\text { bee }\end{array}$ & Bombus vosnesenskii \\
\hline Small carpenter bee & Ceratina acantha \\
\hline Small carpenter bee & Ceratina nanula \\
\hline Gray digger bee & Habropoda depressa \\
\hline Long-horn digger bee & Melissodes lupina \\
\hline Long-horn digger bee & Melissodes robustior \\
\hline Squash bee & Peponapis pruinosa \\
\hline Cuckoo bee & Xeromelecta californica \\
\hline Large carpenter bee & $\begin{array}{l}\text { Xylocopa tabaniformis } \\
\text { orpifex }\end{array}$ \\
\hline \multicolumn{2}{|l|}{ Colletidae } \\
\hline Masked bee & Hylaeus polifolii \\
\hline \multicolumn{2}{|l|}{ Halictidae } \\
\hline Ultra-green sweat bee & Agapostemon texanus \\
\hline Large sweat bee & Halictus farinosus \\
\hline Spined-cheek sweat bee & Halictus ligatus \\
\hline Small sweat bee & Halictus tripartitus \\
\hline Tiny sweat bee & $\begin{array}{l}\text { Lasioglossum } \\
\text { incompletus }\end{array}$ \\
\hline \multicolumn{2}{|l|}{ Megachilidae } \\
\hline Leafcutting bee & Megachile angelarum \\
\hline Leafcutting bee & Megachile fidelis \\
\hline Leafcutting bee & Megachile montivaga \\
\hline Alfalfa leafcutting bee* & Megachile rotundata* \\
\hline Mason bee & Osmia coloradensis \\
\hline Blue orchard bee (BOB) & $\begin{array}{l}\text { Osmia lignaria } \\
\text { propinqua }\end{array}$ \\
\hline
\end{tabular}

to their pollen host plants when foraging for nectar. Recent plantings of squash (Cucurbita spp.) flowers at the UC Berkeley Oxford Tract garden have attracted the specialist squash bee (Peponapis pruinosa), which has been historically recorded in urban Berkeley. We also found a female of the sunflower bee (Diadasia enavata), a sunflower specialist, where sunflower is present in this garden.

Specialist bees (with preferred host plant genera in parentheses) that have been encountered in our garden surveys include: Andrena auricoma (Zygadaenus), Diadasia bituberculata (Calystegia), Diadasia diminuta (Sphaeraclea), Diadasia enavata (Helianthus), Diadasia laticauda (Sphaeraclea), Diadasia nitidifrons 


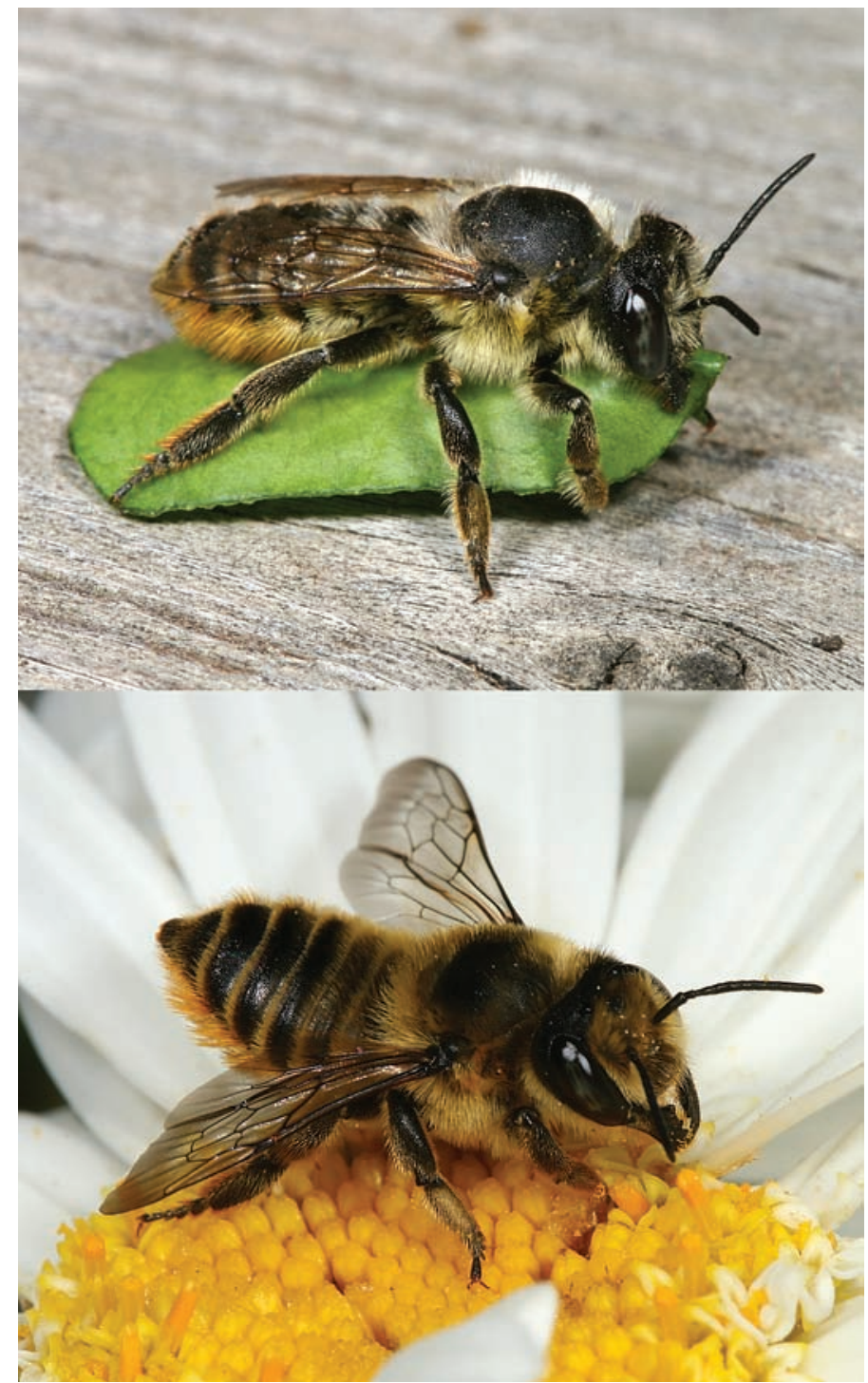

The leafcutting bee (Megachile perihirta) was found in many of the gardens surveyed. Top, a female carries a cut piece of leaf; above, a female with strongly developed mandibles lands on a cosmos flower (Cosmos bipinnatus).

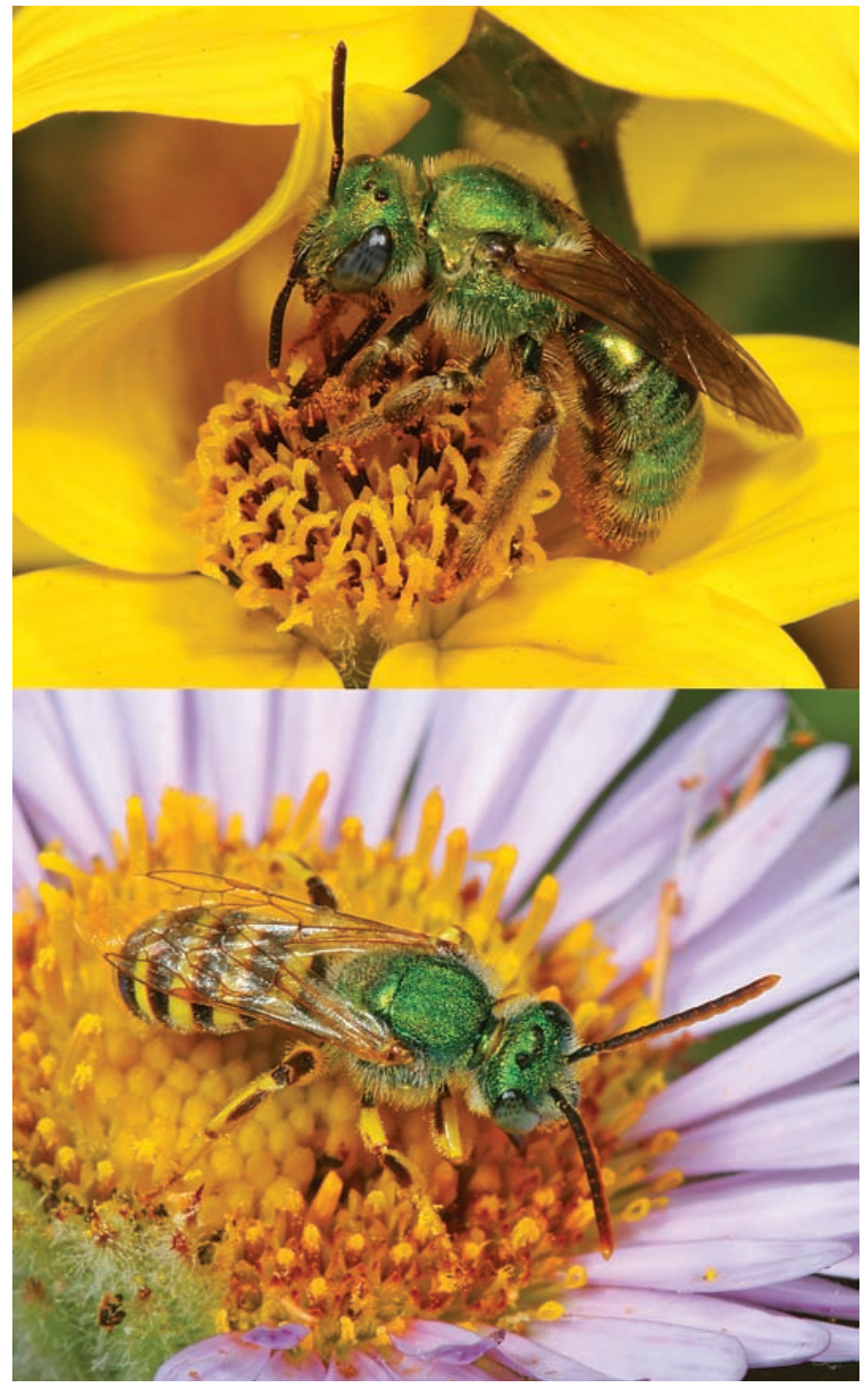

Some 60 to 80 species were identified in each city; the ultra-green sweat bee (Agapostemon texanus) was among the most common. Top, a female on bidens (Bidens ferulifolia); above, a male on sea daisy (Erigeron glaucus).
(Sphaeraclea), Peponapis pruinosa (Cucurbita), Svastra obliqua expurgata (Helianthus), Chelostoma marginatum (Phacelia) and Chelostoma phaceliae (Phacelia).

Seasonal bees. Seven plant types flowered during both spring and summer and attracted several bee taxa that were seasonal to each period (tables 1 and 2). Five of these plants were in the third category of attracting diverse native bees without prominent groups (table 2). With additional sampling, lavenders (table 1B) may eventually be moved to the third category as well. Bee species visiting bidens (Bidens ferulifolia) and catnip mint species provide examples of this pattern. Depending on the city, between 8 and 14 bee species visited these two plant types where adequate samples had been taken (Ukiah, Sacramento and Berkeley for bidens; Ukiah, Sacramento and La Cañada Flintridge for catnip mint). One highly diverse bee group that was attracted to both plant types in the spring was the Megachilidae, especially members of the genera Megachile and Osmia.

Timing of bee visits. Most beefrequency counts and collections in 2005 and 2006 were done opportunistically, that is during whatever time of day bees could be observed and recorded. In 2007, more attention was paid to time of day for the main visitation period. While more focused work is needed for more plant species, bees appeared to visit flowers throughout most of the day for most plant types. However, for some plant types, the greatest bee diversity could be observed during particular times of the day (table 5). Main attraction periods could best be observed on warm, sunny days with little or no wind; however, if the day started off with fog, coolness and/or wind, these periods would be delayed or obscured, with reduced bee activity.

\section{Bee-plant variations}

As indicated, the relationships between each of the target plants and visiting bee groups (tables 1 and 2) were almost the same in Northern California 
and Southern California. One notable exception was observed in Sacramento, where five plant types were visited at high frequencies by a large solitary anthophorid bee (Svastra obliqua expurgata), a local Central Valley species. Four of the five plants - cosmos (C. sulphureus), blanket flower, sunflower and blackeyed Susan (Rudbeckia hirta) - were also visited by Melissodes species, a taxonomic relative of $S$. obliqua expurgata and also the predominant bee group visiting these four plants throughout the state. The fifth plant, chaste tree, was also visited at high levels by S. obliqua expurgata. In other cities, honey bees and leafcutting bees (Megachilidae) were the main visitors (table 1B).

There were several small variations within cities (tables 1 and 2). However, while these variations influenced monitoring, they did not change the placement of a plant in one of the three categories. In Sacramento, rosemary (Rosmarinus spp.) attracted diverse bee taxa in one garden but primarily honey bees and halictid bees in a second garden 2 miles (3 kilometers) away. In a large, diverse San Luis Obispo garden, long-horn digger bees were common in late spring but extremely rare to absent during summer. In contrast, in a second San Luis Obispo garden 3.1 miles (5 kilometers) away, long-horn digger bees were common all summer on plants such as cosmos (C. bipinnatus and C. sulphureus). This type of variation was addressed by increasing the replications of frequency counts and monitoring several gardens in the surveyed cities.

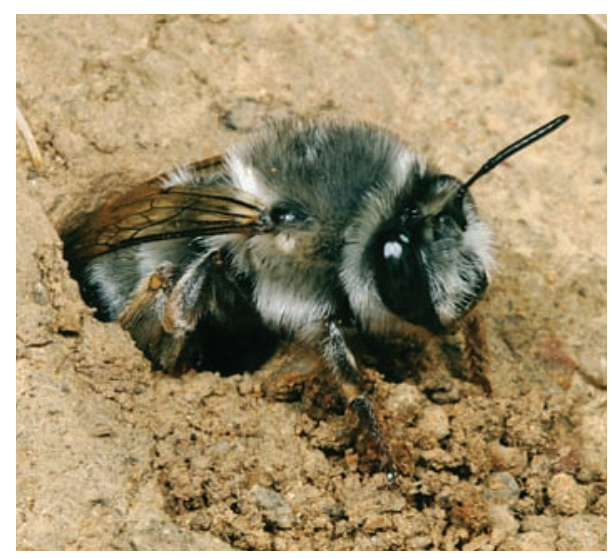

Solitary (nonsocial) bees will nest in a variety of substrates in urban gardens. The digger bee (Anthophora edwardsii) nests in bare dirt.

TABLE 5. Selected plant types and periods of greatest daily bee attraction*

\begin{tabular}{|c|c|c|c|}
\hline Plant type & $\begin{array}{l}\text { Period of greatest } \\
\text { attraction }\end{array}$ & Floral resource & Bee taxa \\
\hline Goldenrod (Solidago californica) & 11 a.m.-3 p.m. & Pollen/nectar & $\begin{array}{l}\text { Halictidae, } \\
\text { Megachilidae, } \mathrm{Hbt,} \\
\text { Bombus }\end{array}$ \\
\hline Pumpkins, squash (Cucurbitaceae) & Before 9 a.m. & Pollen & Peponapis pruinosa, $\mathrm{Hb}$ \\
\hline Palo verde (Parkinsonia aculeata) & Before 10 a.m. & Nectar & $\mathrm{Hb}$, Xylocopa \\
\hline California poppy (Eschscholzia californica) & Before 11 a.m. & Pollen & Bombus, Halictidae, $\mathrm{Hb}$ \\
\hline Wild lilac (Ceanothus spp.) & Before noon & Pollen/nectar & Diverse native bees \\
\hline
\end{tabular}

\section{Target plant abundance}

The presence, absence or abundance of target plants in the cities also influenced bee frequencies. Target plants were infrequent in a few cities, but while this often resulted in overall lower bee counts, it did not affect the placement of plants into the three categories (tables 1 and 2). These plants include bidens (B. ferulifolia), sea daisy (Erigeron glaucus), black-eyed Susan, tansy phacelia (Phacelia tanacetifolia) and black sage (Salvia mellifera). Some target plants, including large perennials such as pride of Madeira (Echium candicans), palo verde and sky flower (Duranta erecta), could not be found in a few cities.

The differences that we found in ornamental plant presence and abundance are important variables, suggesting different gardening practices and plant availability and selection among cities. These variables can greatly influence bee populations by determining the overall amounts of their preferred floral resources. In this regard, some urban areas (such as Monterey-Carmel-Pacific Grove, Paso Robles and San Diego) were not selected for the survey because they lacked diverse and sufficient bee plants. At the opposite extreme were the diverse gardens of Berkeley and Santa Cruz, where species-rich and abundant collections of plants that bees preferred were found. The five other surveyed cities were intermediate in bee-friendly plant diversity and abundance.

\section{Nesting in urban areas}

Bees are known to nest in various substrates in urban areas. Most solitary bees (about 70\%) nest in the ground, including Andrena (Andrenidae), Colletes (Colletidae), most halictid bees (Halictidae), most Anthophorinae (Apidae) and some Megachilidae. (Solitary means a male and a female bee mate, and the female constructs a nest and lays an egg in each single cell she creates, with 3 to 10 cells per nest depending on space; there is no hive, division of labor or social structure as in the social honey bees and bumble bees.) Many of these solitary bees prefer to construct their nests in soils with specific characteristics, such as composition, texture, compaction, slope and exposure. Nesting habitat can be provided for these bees in gardens by leaving bare soil and providing areas of specially prepared soil, from sand to heavy clay to adobe blocks. Excessive mulching with wood chips will greatly discourage ground-nesting bees, which need bare soil or a thin layer of natural leaf litter.

Other bees nest in pre-existing cavities. Honey bees nest in large tree cavities, underground and in human structures such as the spaces between walls, chimneys and water-meter boxes. Bumble bees commonly nest in abandoned rodent burrows and sometimes in bird nest boxes. Most cavitynesting solitary bees such as Hylaeus (Colletidae), and most leafcutting bees and mason bees (Osmia [Megachilidae]) prefer beetle burrows in wood or hollow plant stems. Nest habitats for these bees can be supplemented by drilling holes of various diameters (especially $3 / 16$ to $5 / 16$ inches) in scrap lumber or fence posts, or by making and setting out special wooden domiciles in the garden (Thorp et al. 1992). Once occupied by bees, these cavities must be protected from sun and water exposure until the following year, when adult bees emerge to start new generations. 
Neglecting to protect drilled cavities occupied by bees can lead to bee mortality.

Large carpenter bees (Xylocopa) excavate their nest tunnels in soft wood such as redwood arbors or fences, and small carpenter bees (Ceratina) use pithy stems such as elderberry or old sunflower stalks. Partitions between the brood cells are usually composed of bits of excavated material.

\section{Bee diversity and conservation}

Several studies in Europe, North America, Central America and South America confirm that urban areas can support rich faunas of bees (Cane 2005; Eremeeva and Sushchev 2005; Frankie et al. 2005; Hernandez et al. 2009; Matteson et al. 2008; Wojcik et al. 2008). Furthermore, long-term monitoring has shown that small urban areas can sometimes have relatively high percentages of the bee species found in the surrounding geographic region. For example, Owen (1991) recorded 51 bee species during a 15-year monitoring study in a small residential garden in Leicestershire, England, representing an amazing $20 \%$ of the British bee list of 256 species.

The main pattern that emerges from the statewide California survey is that a predictable group of native bee species can be expected to visit certain ornamental plants (tables 1 and 2). With this kind of information, gardens can be planned with predictable relationships between bees and ornamental plants. The California survey also revealed that not all urban areas can be expected to support measurable populations of native bees. Urban areas must have the right plant types, and enough of them, to attract native bees. Predictable beeflower relationships are well known among wildland plants and native bee taxa that visit them in California and elsewhere (G. Frankie and R. Thorp, personal observation).

Much is still unknown about the ecology and behavior of native bees in urban environments, especially regarding how to encourage the bees to visit gardens. Our monitoring work will continue for at least two more years, with the same target plants in the same seven cities. We also added two additional cities: Redding, in far north-

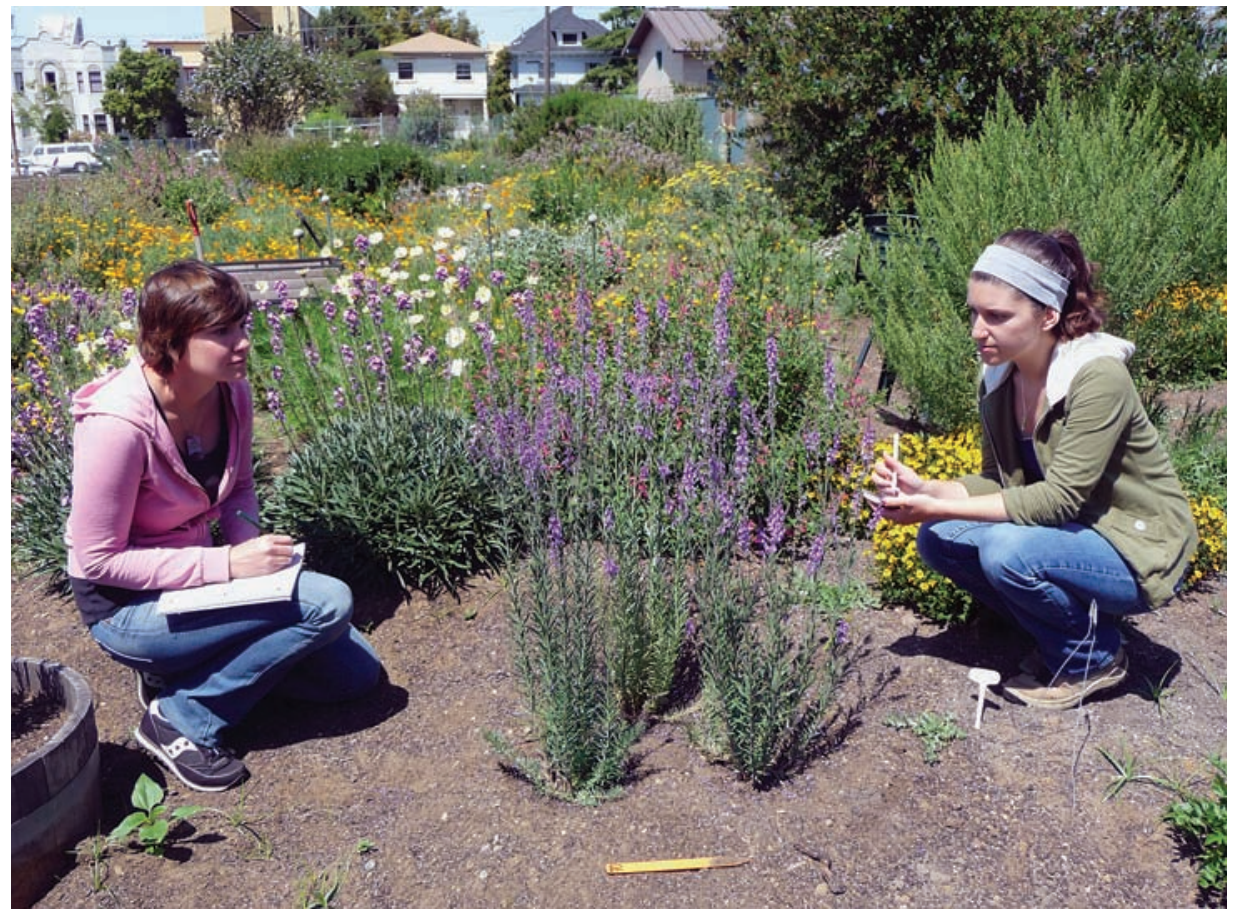

Almost 2,500 3-minute bee-frequency counts were conducted statewide over a 2-year study period. At the UC Berkeley Oxford Tract, researchers Jaime Pawelek (left) and Katie Montgomery counted bees on purple toad flax; note the garden's close proximity to residential neighborhoods.

central California, and Riverside, southeast of Pasadena. More attention will be paid to bee-plant relationships within cities and also to temporal visitation patterns, which will provide more accurate information on the optimal times of day to record the greatest diversity and abundance of bees.

From a biodiversity perspective, it is easy to understand why we should conserve and protect native bees. The approximately 1,600 species of native California bees have had a long evolutionary history with about 6,000 different kinds of native California flowering plants. Like the plants, bees are an integral part of the heritage of the state's natural resources. Despite the fact that most gardens in the state use a high percentage of nonnative plants (instead of the native plants preferred by native bees), they are nonetheless visited by native bees (Frankie et al. 2005).

Likewise, there is still much to be learned about how to convey scientific knowledge in user-friendly language to urban audiences. Native bees can be used as "tools" for a range of activities, including habitat gardening, environmental education and scientific inquiry to solve current environmental problems. Great opportunities exist for increasing biodiversity in home, school and community gardens if the right plants are grown. Besides bees, the plants will attract other flower visitors such as birds, butterflies and beneficial flies and wasps (Grissell 2001). Once established, diverse gardens offer opportunities to observe, conserve, protect and enjoy a variety of floral ecological relationships close to home. In the case of school gardens, which usually have mixtures of food and ornamental plants, teachers have opportunities to connect students with the natural world (Louv 2008) as well as the world from which our food comes.

Information on pollinator-plant relationships can be used for more ambitious projects such as restoring ecological functions to degraded or fallowed landscapes (Peter Kevan, University of Guelph, Canada, personal communication). Some larger urban gardens with high plant diversity can be used as stations for long-term pollinator monitoring (NRC 2007) that could provide valuable information, especially as the global climate changes; in Sacramento and La Cañada Flintridge, 
two of our largest survey gardens are being used for this purpose. It is noteworthy that urban landscape gardens may be more suitable for monitoring certain bee pollinator species than wild areas because urban plants are usually intensively managed. Watering, pruning and replanting produces floral resources that are more consistently available to pollinators, even in times of drought.

As suggested by Owen (1991), urban areas can serve as genetic reserves for pollinators and other species that we deem beneficial for humans. Some of these may eventually be a resource for the pollination of agricultural crops (G. Frankie and R. Thorp, personal observation). The effects of colony collapse disorder in honey bees (NRC 2007) once again remind us of the need to consider the value of ecological services provided in biodiverse landscapes (Daily 1997).

G.W. Frankie is Professor, Department of Environmental Science, Policy and Management, UC Berkeley; R.W. Thorp is Professor Emeritus, Department of Entomology, UC Davis; J. Hernandez is Ph.D. Researcher, Department of Environmental Science, Policy and Management, UC Berkeley; M. Rizzardi is Professor, Department of Mathematics, Humboldt State University; B. Ertter is Curator Emeritus, Jepson Herbarium, UC Berkeley; J.C. Pawelek, S.L. Witt and M. Schindler are Research Assistants, Department of Environmental Science, Policy and Management, UC Berkeley; R. Coville is Environmental Entomologist/Photographer; and V.A. Wojcik is Graduate Researcher, Department of Environmental Science, Policy and Management, UC Berkeley. All bee photos were taken by Rollin Coville.

We thank the California Agricultural Experiment Station for support of this research; Maggie Przybylski, Sue Holland, Katie Montgomery, Kristal Hinojosa and Kloie Karels for assistance in collecting bees and bee-frequency counts; and Peter Kevan for reading a draft of the manuscript. Finally, we thank the numerous gardeners, managers and directors of the gardens we monitored for their cooperation during survey periods.

\section{For more information}

North American Pollinator Protection Campaign

www.pollinator.org

Urban Bee Gardens

http://nature.berkeley.edu/urbanbeegardens

The Xerces Society for Invertebrate Conservation www.xerces.org

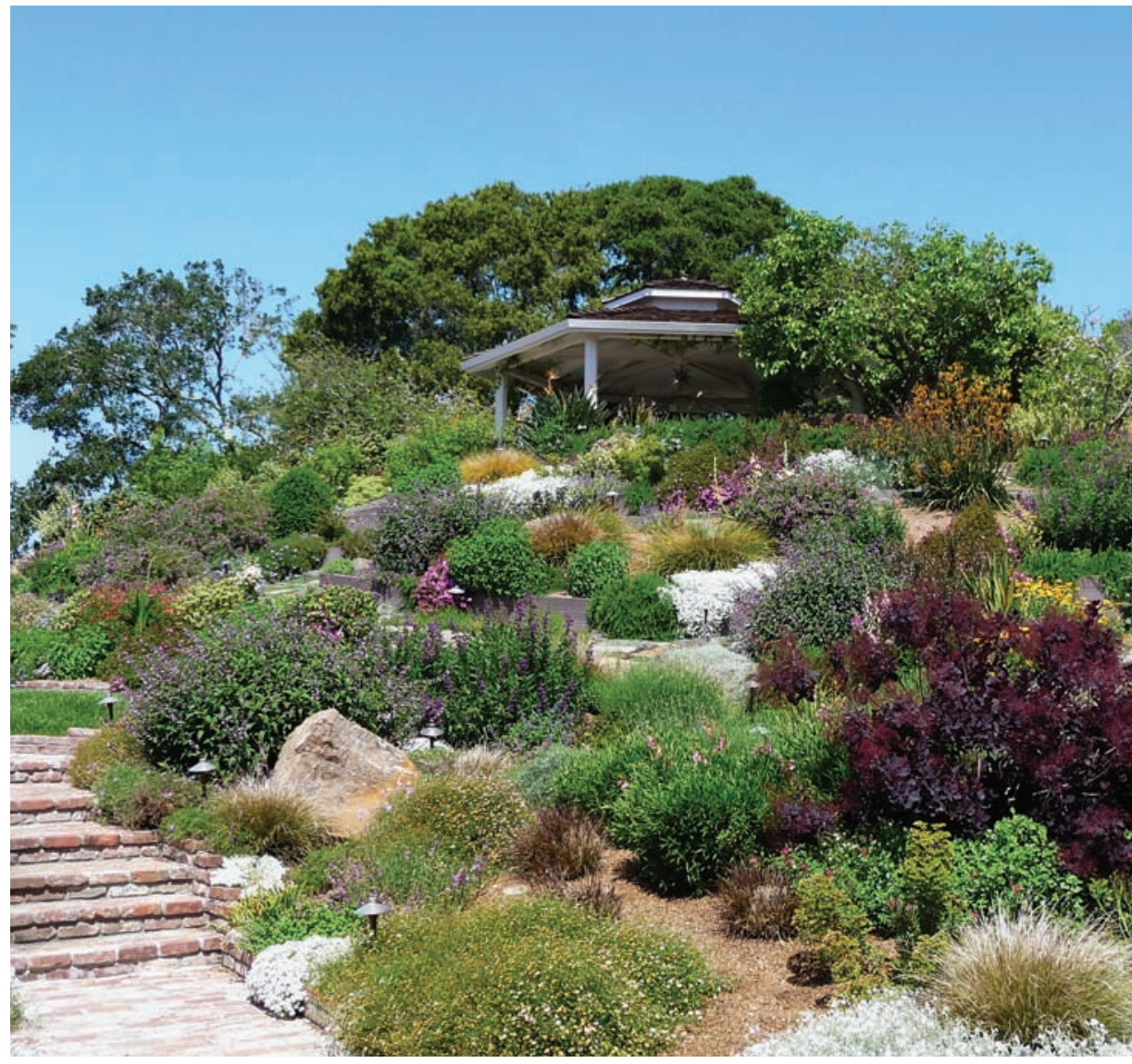

The study found that while many urban gardens include a high percentage of nonnative ornamental plants, a great variety of native bees visit them. Above, Kimberly Gamble's garden in Soquel (Santa Cruz County).

\section{References}

Allen-Wardell G, Bernhardt P, Bitner R, et al. 1998. The potential consequences of pollinator declines on the conservation of biodiversity and stability of food crop yields. Conserv Biol 12:8-17

Brenzel KN (ed.). 2007. Sunset Western Garden Book Menlo Park, CA: Sunset Pub. 768 p.

Cane JH. 2005. Bees, pollination and the challenges of sprawl. In: Johnson EA, Klemens MW (eds.). Nature in Fragments. New York: Columbia Univ Pr. 382 p

Daily G. 1997. Nature's Services: Societal Dependence on Natural Ecosystems. Covelo, CA: Island Pr. 392 p.

Eremeeva NI, Sushchev DV. 2005. Structural changes in the fauna of pollinating insects in urban landscapes. Russ J Ecol 36:259-65.

Frankie GW, Ehler LE. 1978. Ecology of insects in urban environments. Ann Rev Entomol 23:367-87.

Frankie GW, Thorp RW, Schindler M, et al. 2005. Ecological patterns of bees and their host ornamenta flowers in two northern California cities. J Kansas Entomol Soc 78:227-46.

Grissell E. 2001. Insects and Gardens. Portland, OR: Timber Pr. $345 \mathrm{p}$.

Hernandez JL, Frankie GW, Thorp RW. 2009. Diversity and abundance of native bees (Hymenoptera: Apoidea) in a newly constructed urban garden in Berkeley, California. J Kansas Entomol Soc (accepted).
Kremen C, Williams NM, Bugg RL, et al. 2004. The area requirements of an ecosystem service: Crop pollination by native bee communities in California. Ecol Letter 7:1109-19.

Kremen C, Williams NM, Thorp RW. 2002. Crop pollination from native bees at risk from agricultural intensification. PNAS 99:16812-8.

Louv R. 2008. Last Child in the Woods: Saving Our Children from Nature-Deficit Disorder. New York: Algonquin. 391 p.

Matteson KC, Ascher JS, Langellotto GA. 2008. Bee richness and abundance in New York City urban gardens. Ann Entomol Soc Am 101:140-50.

[NRC] National Research Council. 2007. Status of Pollinators in North America. Washington, DC: Nat Acad Pr. 307 p.

Owen J. 1991. The Ecology of a Garden: The First Fifteen Years. Cambridge, Eng.: Cambr Univ Pr. 403 p.

Tallamy DW. 2009. Bringing Nature Home. Portland, OR: Timber Pr. 358 p.

Thorp RW, Frankie GW, Barthell J, et al. 1992. Longterm studies to gauge effect of invading bees. Cal Ag 46(1):20-3.

Wojcik VA, Frankie GW, Thorp RW, Hernandez J. 2008. Seasonality in bees and their floral resource plants at a constructed urban bee habitat in Berkeley, California. J Kansas Entomol Soc 81:15-28. 